\title{
Relationship between two year PSA nadir and biochemical recurrence in prostate cancer patients treated with iodine-125 brachytherapy"
}

A relação entre PSA nadir de dois anos e recidiva bioquímica no tratamento do câncer de próstata com braquiterapia de semente de iodo- 125

\section{Carlos Antônio da Silva Franca ${ }^{1}$, Sérgio Lannes Vieira ${ }^{2}$, Antonio Carlos Pires Carvalho ${ }^{3}$, Antonio Jose Serrano Bernabe $^{4}$, Antonio Belmiro Rodrigues Campbell Penna ${ }^{5}$}

Franca CAS, Vieira SL, Carvalho ACP, Bernabe AJS, Penna ABRC. Relationship between two year PSA nadir and biochemical recurrence in prostate cancer patients treated with iodine-125 brachytherapy. Radiol Bras. 2014 Mar/Abr;47(2):89-93.

Abstract Objective: To evaluate the relationship between two year PSA nadir (PSAn) after brachytherapy and biochemical recurrence rates in prostate cancer patients.

Materials and Methods: In the period from January 1998 to August 2007, 120 patients were treated with iodine-125 brachytherapy alone. The results analysis was based on the definition of biochemical recurrence according to the Phoenix Consensus.

Results: Biochemical control was observed in 86 patients (71.7\%), and biochemical recurrence, in 34 (28.3\%). Mean PSAn was 0.53 $\mathrm{ng} / \mathrm{ml}$. The mean follow-up was 98 months. The patients were divided into two groups: group 1, with two year PSAn $<0.5 \mathrm{ng} / \mathrm{ml}$ after brachytherapy (74 patients; 61.7\%), and group 2, with two year PSAn $\geq 0.5 \mathrm{ng} / \mathrm{ml}$ after brachytherapy (46 patients; $38.3 \%$ ). Group 1 presented biochemical recurrence in 15 patients (20.3\%), and group 2, in 19 patients (43.2\%) $(p<0.02)$. The analysis of biochemical disease-free survival at seven years, stratified by the two groups, showed values of $80 \%$ and $64 \%(p<0.02)$, respectively.

Conclusion: Levels of two year PSAn $\geq 0.5 \mathrm{ng} / \mathrm{ml}$ after brachytherapy are strongly correlated with a poor prognosis. This fact may help to identify patients at risk for disease recurrence.

Keywords: PSA nadir; Brachytherapy; lodine radioisotopes; Prostatic neoplasms.

Resu mo Objetivo: Avaliar os valores de PSA nadir (PSAn) dois anos após braquiterapia e sua relação com a taxa de recidiva bioquímica. Materiais e Métodos: Cento e vinte pacientes foram tratados no período de janeiro de 1998 a agosto de 2007 . Todos os pacientes foram submetidos a braquiterapia isolada. Os resultados foram analisados com base na definição de recidiva bioquímica do Consenso Phoenix.

Resultados: Oitenta e seis pacientes (71,7\%) tiveram controle bioquímico e 34 (28,3\%) apresentaram recidiva bioquímica. 0 PSAn médio foi $0,53 \mathrm{ng} / \mathrm{ml}$. 0 seguimento médio foi 98 meses. Os pacientes foram divididos em dois grupos: grupo 1, com PSAn < 0,5 ng/ml dois anos após a braquiterapia (74 pacientes; $61,7 \%$ ), e grupo 2, com PSAn $\geq 0,5 \mathrm{ng} / \mathrm{ml}$ dois anos após a braquiterapia (46 pacientes; 38, 3\%). 0 grupo 1 teve recidiva bioquímica em 15 pacientes (20,3\%) e o grupo 2 em 19 pacientes (43,2\%) $(p<0,02)$. A análise da sobrevida livre de doença bioquímica de sete anos, estratificada pelos dois grupos, apresentou valores de $80 \%$ e $64 \%(p<0,02)$, respectivamente.

Conclusão: Os níveis de PSAn $\geq 0,5 \mathrm{ng} / \mathrm{ml}$ dois anos após a braquiterapia estão fortemente correlacionados com mau prognóstico. Este fato pode ajudar a identificar pacientes com risco de recidiva da doença.

Unitermos: PSA nadir; Braquiterapia; Radioisótopos do iodo; Neoplasia de próstata.

* Study developed at Radioterapia Botafogo, with support of Instituto Brasileiro de Oncologia (IBO), Universidade Federal do Rio de Janeiro (UFRJ) and Pontifícia Universidade Católica do Rio de Janeiro (PUC-Rio), Rio de Janeiro, RJ, Brazil.

1. Master, MD, Radiation Oncology at Instituto Brasileiro de Oncologia (IBO), Radioterapia Botafogo, Universidade Federal do Rio de Janeiro (UFRJ) and Pontifícia Universidade Católica do Rio de Janeiro (PUC-Rio), Rio de Janeiro, RJ, Brazil.

2. Full Professor, MD, Radiation Oncology at Instituto Brasileiro de Oncologia (IBO), Radioterapia Botafogo and Pontifícia Universidade Católica do Rio de Janeiro (PUC-Rio), Rio de Janeiro, RJ, Brazil.

3. PhD, Professor at Universidade Federal do Rio de Janeiro (UFRJ), Rio de Janeiro, RJ, Brazil.

4. MD, Urologist at Radioterapia Botafogo, Rio de Janeiro, RJ, Brazil.

5. PhD, MD, Radiation Oncology at Instituto Brasileiro de Oncologia (IBO), Radioterapia Botafogo and Pontifícia Universidade Católica do Rio de Janeiro (PUC-Rio), Rio de Janeiro, RJ, Brazil.

\section{INTRODUCTION}

According to the World Health Organization, prostate cancer is the second type of cancer in incidence in men, and also the sixth most frequent cause of death in the male population worldwide ${ }^{(1)}$. In Brazil, 68,880 new cases of prostate cancer were estimated for 2014. Such number of cases corresponds to an estimated risk of 70.42 new cases per 100,000 men $^{(2)}$.

Mailing Address: Dr. Carlos Antônio da Silva Franca. Rua Marechal Niemeyer, 16, Botafogo. Rio de Janeiro, RJ, Brazil, 22251-060. E-mail: carlosfranca@cremerj.org.br Received April 9, 2013. Accepted after revision October 22, 2013. 
Radiotherapy is utilized in the treatment of prostate cancer either as exclusive or adjuvant therapy, or after biochemical recurrence, therefore it represents an important oncologic treatment technique $^{(3-5)}$. Prostatic specific antigen (PSA) test is the main method for detection of biochemical recurrence of prostate cancer. Finding a prognosis marker to identify men at high risk for treatment failure and subsequent death could be useful to select those patients who might benefit from early rescue therapy. Several PSA variables are tested in order to predict biochemical control, including initial PSA (PSAi) and PSA nadir (PSAn) ${ }^{(6)}$.

After radiotherapy, PSA levels gradually decline after a period of 18-24 months. Fluctuations of PSA are not infrequent, with transient increases and subsequent drops called bounces $^{(7)}$. The PSAn is defined as the lowest PSA value measured after utilization of any treatment method. The time required to reach PSAn is different for radical prostatectomy and for external radiotherapy. After surgery, PSA levels decline is immediate, dropping to undetectable levels soon after the intervention, while after radiotherapy the decrease is slow, taking up to 27 months to reach PSAn. Patients who reach PSAn within the first 12 months after radiotherapy present with worse prognosis, with a relative risk for disease recurrence 18 times higher than that observed in those patients whose PSAn occurs two years after such a treatment ${ }^{(8)}$.

Brachytherapy has increasingly been utilized, because of the technological developments in transrectal ultrasonography, availability of radioactive iodine sources adapted for implantation in the prostate gland, and the development of computer-aided planning systems for such therapeutic method ${ }^{(9,10)}$. It is an outpatient procedure, with low morbidity rates, good conformity to the target lesion, excellent dose distribution and better quality of life for the patient ${ }^{(9,10)}$. In the USA, $36 \%$ of radiotherapy treatments for prostate cancer consist of brachytherapy ${ }^{(11)}$. The initial success of such a treatment has led to a dramatic increase in its utilization in patients with focal prostate cancer worldwide ${ }^{(12)}$. The advantages of brachytherapy include its conformational property; concentration of high radiation doses within the target volume; and rapid dose decline in adjacent structures such as the bladder and rectum ${ }^{(10,13)}$.

Several studies have demonstrated the relationship between PSAn after definitive radiotherapy and biochemical disease-free survival (BDFS) ${ }^{(14-16)}$. Although most patients experience a decrease in PSA levels after definitive radiotherapy, only few of them reach undetectable PSA levels ${ }^{(16)}$. Several authors have proposed a cut-off point for various PSAn levels, ranging from 0.2 to $4.0 \mathrm{ng} / \mathrm{ml}$, as a predictive factor for biochemical recurrence in patients submitted to radiotherapy, brachytherapy or a combination of both treatments, either with or without androgen suppression ${ }^{(6,15,17,18)}$.

The present study was aimed at evaluating the relationship between PSAn values two years after iodine-125 brachytherapy and chances of biochemical prostate cancer recurrence.

\section{MATERIALS AND METHODS}

The study was duly approved by the Committee for Ethic in Research of Hospital Universitário Clementino Fraga Filho - Universidade Federal do Rio de Janeiro, Brazil.

From January 1998 to August 2007, 120 consecutive prostate cancer patients (T1-T2) referred by different urologists were submitted to isolated brachytherapy. All the patients underwent follow-up from January 2001 to December 2012. The patients were classified into three categories of recurrence risk groups, also utilized by D'Amico ${ }^{(19)}$, based on prognostic factors such as PSAi, Gleason score and clinical stage, which evaluate the risk for biochemical recurrence after any type of treatment:

- Low risk: PSAi $<10.0 \mathrm{ng} / \mathrm{ml}$, Gleason $\leq 6$ and clinical stage $=$ T1b-T2a

- Intermediate risk: PSAi between 10.1 and $19.9 \mathrm{ng} / \mathrm{ml}$ or Gleason $=7$ or clinical stage $=\mathrm{T} 2 \mathrm{~b}$.

- High risk: PSAi $\geq 20.0 \mathrm{ng} / \mathrm{ml}$ or Gleason $\geq 8$ or clinical stage $\geq \mathrm{T} 2 \mathrm{c}$.

PSAi is defined as the last recorded PSA value before the beginning of any treatment. Those patients with a probable life expectancy of less than five years; those with previous transurethral resection causing major deformity of the prostatic urethra; and those with high surgical risk and distant metastases were excluded from the study as per contraindications proposed by the American Brachytherapy Society ${ }^{(20)}$.

All the patients were treated with isolated brachytherapy. Neoadjuvant hormone therapy with one or more luteinizing hormone-release agonists and oral anti-androgens were prescribed by the assisting urologists, for two to four months, whenever the initial prostate volume was above $50 \mathrm{~g}$, with the purpose of reducing the prostate volume, and were interrupted before brachytherapy planning. None of the patients was submitted to external radiotherapy.

The brachytherapy technique proposed by the authors is described in detail in another article $^{(21)}$. Post-implant dosimetry evaluates the technical quality of the implant and the quantified radiation dose delivered to the bladder and to the adjacent rectum, based on pelvic computed tomography performed 30 days after brachytherapy. Criteria for appropriate post-implant dosimetry included $\mathrm{V}_{100}>80 \%, \mathrm{D}_{90}>$ $90 \%$, and $\mathrm{V}_{150}<60 \%$ for iodine- 125 seeds ${ }^{(22)}$. In Brazil, only iodine- 125 seeds are commercially available for low dose rate brachytherapy.

The patients were followed-up every four or six months by means of total PSA level testing and clinical and radiological evaluation, as necessary, in the event of PSA levels increase.

The parameter utilized to evaluate the results was total PSA. The Phoenix Consensus ${ }^{(23)}$ is adopted to define biochemical recurrence, established as PSAn $+2 \mathrm{ng} / \mathrm{ml}$ or in cases where any rescue treatment is initiated. PSAn is the lowest total PSA value recorded after any treatment. 
Several authors have proposed a cut-off value for different PSAn levels, ranging from 0.2 to $4.0 \mathrm{ng} / \mathrm{ml}$, as predictive factor for biochemical recurrence ${ }^{(6,15,17,18)}$. In the present study, the groups were divided according to PSAn $<0.5 \mathrm{ng} /$ $\mathrm{ml}$ or $\geq 0.5 \mathrm{ng} / \mathrm{ml}$ as the cut-off value.

Mean and median values were calculated for results analysis. The following statistical methods were utilized: chisquare test for categorical variables and Student's $t$ test for continuous variables. The adopted significance level was 5\% probability $(p \leq 0.05)$, with a confidence interval of $95 \%$ (CI95\%). The BDFS was analyzed by means of the KaplanMeier curve and the log-rank test. The statistical analysis was carried out by means of the software SPSS for windows, release 13 (SPSS Inc.; Chicago, USA).

\section{RESULTS}

In total, 120 patients were analyzed: 34 patients $(28.3 \%)$ with biochemical recurrence, and $86(71.7 \%)$ presented with biochemical control. Mean PSAn was $0.53 \mathrm{ng} / \mathrm{ml}(0.01-$ 2.00; CI95\%: 0.45-0.61) and the mean follow-up period was 98 months (29-144; CI95\%: 91-104).

In those patients with biochemical control, the mean PSA value was $0.27 \mathrm{ng} / \mathrm{ml}$ (0.01-0.98; CI95\%: 0.23-0.31), and in those patients with biochemical recurrence, it was 0.96 $\mathrm{ng} / \mathrm{ml}$ (0.50-2.00; CI95\%: 0.83-1.08), with $p<0.035$. The mean time for onset of biochemical recurrence was 36 months (5-93; CI95\%: 26-45).

The patients were divided into two groups, as follows: group 1, with 74 patients $(61.7 \%)$ presenting with PSAn $<$ $0.5 \mathrm{ng} / \mathrm{ml}$ two years after brachytherapy; and group 2, with 46 patients (38.3\%) presenting with PSAn $\geq 0.5 \mathrm{ng} / \mathrm{ml}$ two years after brachytherapy. The clinical characteristics of the patients are described in Table 1.

In group 1, 15 patients (20.3\%) with biochemical recurrence, while in group 2, 19 patients $(43.2 \%)$ had biochemical recurrence with $p<0.05$. The analysis of risk factors such as age $(p=0.13)$, PSAi $(p=0.4)$, prostate volume $(p=0.85)$, dosimetric parameters $(p>0.08)$, risk groups $(p=0.3)$, CS $(p=0.06)$ and Gleason score $(p=$ 0.25 ) did not demonstrate any significant association between the two groups.

The analysis of BDFS after seven years of follow-up in groups 1 and 2 was $80 \%$ and $64 \%$ respectively (Figure 1), demonstrating statistical significance of PSAn as a predictive factor of biochemical recurrence $(p<0.02)$.

\section{DISCUSSION}

Miller et al. ${ }^{(24)}$ presented questions on the predictive value of PSAn and whether or not it could be utilized to predict subsequent failure after prostate cancer radiotherapy. Investigators are looking for an early predictor of failure in order to allow for an earlier institution of rescue treatment. However, PSAn might generally take several years to occur, with its lower plateau not being reached even after 8-10 years, continuing to decrease slowly in some cases ${ }^{(25)}$. As a result,
Table 1-Groups' characteristics.

\begin{tabular}{|c|c|c|c|}
\hline & Group 1 & Group 2 & \\
\hline & Mean (Cl95\%) & Mean (CI95\%) & $p$ \\
\hline Age (years) & $68(67-69)$ & $66(65-67)$ & 0.13 \\
\hline PSAi (ng/ml) & $10.7(9.7-11.8)$ & $11.2(10-12.4)$ & 0.4 \\
\hline Volume (g) & $39.6(37.9-41.2)$ & 35 (33.4-36.6) & 0.85 \\
\hline$V_{100}(\%)$ & $83.6(81.7-85.6)$ & $87.3(84.8-89.8)$ & 0.25 \\
\hline $\mathrm{D}_{90}(\%)$ & 97.6 (95.3-100) & 101 (97.8-104.3) & 0.08 \\
\hline$V_{150}(\%)$ & $49.7(47.3-52.1)$ & $56.7(54-59.3)$ & 0.1 \\
\hline Risk groups & Patients (\%) & Patients (\%) & \\
\hline Low & $11(12.2 \%)$ & 5 (16.7\%) & \\
\hline Intermediate & $52(57.8 \%)$ & 15 (50\%) & 0.3 \\
\hline High & 27 (30\%) & 10 (33.3\%) & \\
\hline \multicolumn{4}{|l|}{ PSAi } \\
\hline 0-10 ng/ml & 80 (88.8\%) & 25 (83.3\%) & \multirow{3}{*}{0.25} \\
\hline $10.1-20 \mathrm{ng} / \mathrm{ml}$ & $5(5.6 \%)$ & $3(10 \%)$ & \\
\hline$>20 \mathrm{ng} / \mathrm{ml}$ & $5(5.6 \%)$ & $2(6.7 \%)$ & \\
\hline \multicolumn{4}{|l|}{ Clinical stage } \\
\hline $\mathrm{T} 1 \mathrm{c}-\mathrm{T} 2 \mathrm{a}$ & $16(17.8 \%)$ & $8(26.7 \%)$ & \multirow{2}{*}{0.06} \\
\hline $\mathrm{T} 2 \mathrm{~b}-\mathrm{T} 2 \mathrm{c}$ & 74 (82.2\%) & 22 (73.3\%) & \\
\hline \multicolumn{4}{|l|}{ Gleason score } \\
\hline $2-6$ & $80(88.8 \%)$ & 25 (83.3\%) & \multirow{3}{*}{0.25} \\
\hline 7 & $5(5.6 \%)$ & $3(10 \%)$ & \\
\hline $8-9$ & 5 (5.6\%) & $2(6.7 \%)$ & \\
\hline \multicolumn{4}{|l|}{ NHT } \\
\hline Yes & 46 (51\%) & 16 (53\%) & \multirow{2}{*}{0.52} \\
\hline No & 44 (49\%) & 14 (47\%) & \\
\hline
\end{tabular}

CI95\%, confidence interval at 95\%; NHT, neoadjuvant hormone therapy.

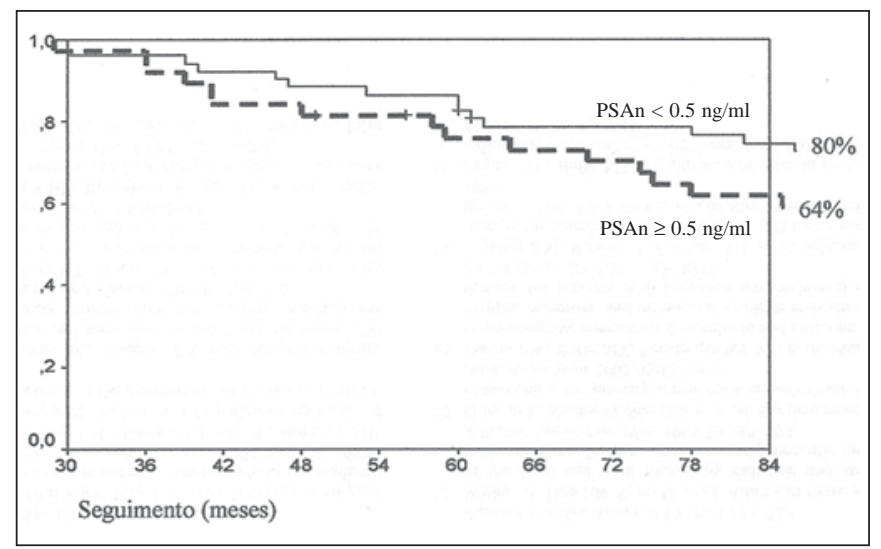

Figure 1. Biochemical disease-free survival.

PSAn would be of little practical clinical value. A much more reasonable approach would be to utilize the lowest PSA value evaluated during a definite and relatively short time interval (for example, 12 months) after completion of radiotherapy. Some authors report that PSAn is significantly related to clinical failure $^{(24,25)}$. The present study includes the PSAn values two years after iodine-125 brachytherapy and the chances of biochemical recurrence in the treatment of prostate cancer.

Kapadia et al. ${ }^{(14)}$ have reviewed several studies with different absolute post-treatment PSAn levels indicative of bio- 
chemical recurrence ranging between $0.2-4.0 \mathrm{ng} / \mathrm{ml}$. No consensus was reached for PSAn values which might identify a factor. In the present study, the PSAn value of $0.5 \mathrm{ng} /$ $\mathrm{ml}$ was utilized as the cut-off value, as such a value corresponded to the median of the sample, providing an almost equitable balancing between the groups in order to reduce sampling bias.

The predictive value of the PSAn levels for biochemical control demonstrated in the present study reinforces the results reported by previous studies ${ }^{(6,7,14-17)}$. However, relevant points should be taken into consideration in the interpretation of such type of analysis, namely: caution in the evaluation of the PSA bounce, excessive time for documenting the biochemical recurrence, substantial differences between biochemical recurrence in the surgical treatment and radiotherapy. The PSAn is a post-treatment factor which is unknown at the moment of irradiation. It is only later determined, after the treatment completion, and varies considerably from patient to patient ${ }^{(6)}$. Additionally, the PSA bounce must be taken into consideration as it occurs in $35 \%$ of the cases after treatment, being described as an increase of PSA followed by subsequent decrease, generally 12 to 24 months after the seeds implant ${ }^{(17)}$. In their analysis, Zelefsky et al. ${ }^{(7)}$ have indicated that the reference time span of two years was a better discriminator as compared with the three-year reference time span for metastases and mortality. If an increase in PSA levels was observed during follow-up, PSA tests were performed at shorter intervals ( 30 days), until the cause of the biochemical failure could be found, in order to avoid the PSA bounce effect.

Kaminski et al. ${ }^{(16)}$ have suggested that post-radiotherapy PSAn is more significant in patients at a high risk for biochemical recurrence, such as in the case of patients at advanced clinical stages of disease, those presenting with high Gleason score or high PSAi. In the present study, patients from all risk classes were included, and none of them demonstrated statistically significant differences.

Neoadjuvant hormone therapy has been utilized by some patients and that might affect the PSAn values due to the changes in the PSA levels ${ }^{(7,16)}$. However, in the present study, PSAn was not significantly influenced by the utilization of neoadjuvant hormone therapy.

Kaminski et al. ${ }^{(16)}$ have demonstrated that the prostate volume is predictive for PSAn, as larger prostates might lead to higher PSAn values. In the present study, the evaluation of prostate volume and PSAn did not demonstrate any statistical difference.

Zelefsky et al. ${ }^{(12)}$ have found out that the PSAn level was predictive of biochemical control at long term, since relatively low PSAn values seem to reflect high intraprostatic doses delivered by interstitial brachytherapy as a result from the ablation of malignant and normal cells on the production of PSA in the prostate epithelium, as the prostatic epithelial cells are responsible for the PSA serum levels ${ }^{(4)}$, and higher radiation doses in the prostate volume are, probably, directly related to the decrease in such an antigen levels ${ }^{(4)}$. Thus, one might conclude that higher $D_{90}$ and $V_{100}$ would be related to lower PSAn values, demonstrating the importance of the radiation dose as higher doses are associated with lower PSAn values and better biochemical control ${ }^{(2,26-28)}$. However, the present study did not demonstrate any influence of $D_{90}$ and $V_{100}$ on the PSAn values.

Pinkawa et al. ${ }^{(29)}$ report that PSAn is highly relevant for the prognosis, since all their patients with PSAn $<0.1 \mathrm{ng} /$ $\mathrm{ml}$ remained free of recurrence $(100 \%)$ while those with PSAn $<0.5 \mathrm{ng} / \mathrm{ml}$ remained free of recurrence in $87 \%$ of the cases. In the present study, the BDFS rate for PSAn $<0.5$ $\mathrm{ng} / \mathrm{ml}$ was $80 \%$, very close to that in the mentioned study.

The rate of five-year BDFS found by Nickers et al. ${ }^{(30)}$ and Cury et al. ${ }^{(31)}$ was $95 \%$ for PSAn $<1.0 \mathrm{ng} / \mathrm{ml}$, and $57 \%$ for PSAn $\geq 1.0 \mathrm{ng} / \mathrm{ml}$. Lee et al. ${ }^{(32)}$ recorded rates of $99 \%$ and $49 \%$, respectively, for PSAn $<1.0 \mathrm{ng} / \mathrm{ml}$ and PSAn $\geq$ $1.0 \mathrm{ng} / \mathrm{ml}$. Such data are consistent with those from the present study. Critz et al. ${ }^{(33)}$ have reported that all patients with PSAn $>1.0 \mathrm{ng} / \mathrm{ml}$ after five years have greater probability of biochemical recurrence, in spite of the utilization of brachytherapy in association with radiotherapy. Other authors ${ }^{(14,34)}$ have found a five-year BDFS of $32 \%$ for patients with PSAn $\geq 1.0 \mathrm{ng} / \mathrm{ml}$. In the present study, with seven years of actuarial analysis of BDFS of patients with PSAn $\geq 0.5$ $\mathrm{ng} / \mathrm{ml}$, the BDFS was $64 \%$ two years after isolated brachytherapy.

Recently, Chen et al. ${ }^{(35)}$ concluded that PSAn $<0.49$ $\mathrm{ng} / \mathrm{ml}$ two years after radiotherapy translated into better long term biochemical control, as does the present study.

The present study had the following limitations: retrospective analysis, patients referred by different assisting urologists, staging performed by means of transrectal ultrasonography and difficulty in comparing data with those reported by other authors because of samples heterogeneity both in Brazil and abroad.

\section{CONCLUSIONS}

The results from the present study suggest that PSAn can be a predictive factor for biochemical recurrence. Levels of PSAn $\geq 0.5 \mathrm{ng} / \mathrm{ml}$ two years after brachytherapy are strongly associated with a poor prognosis. Such a fact can be useful to identify patients at risk for disease recurrence.

A longer follow-up time and a higher number of patients are necessary to confirm data from the present study.

\section{Acknowledgements}

To Jennifer Uribe $\left(\right.$ Oncura $\left.^{\mathrm{TM}}\right)$, responsible for the introduction of iodine- 125 brachytherapy in Brazil.

\section{REFERENCES}

1. Castro HAS, Iared W, Shigueoka DC, et al. Contribuição da densidade do PSA para predizer o câncer da próstata em pacientes com valores de PSA entre 2,6 e 10,0 ng/ml. Radiol Bras. 201 1;44:205-9.

2. Brasil. Ministério da Saúde. Instituto Nacional de Câncer. Estimativa/2014 - Incidência de câncer no Brasil. Rio de Janeiro: INCA; 
2014. [acessado em 17 de março de 2014]. Disponível em: http:// www.inca.gov.br/estimativa/2014/estimativa-24012014.pdf.

3. Rolim AEH, Costa LJ, Ramalho LMP. Repercussões da radioterapia na região orofacial e seu tratamento. Radiol Bras. 2011;44:38895.

4. Silva AIV, Galante C, Manzi FR. Efeito da radiação ionizante sobre o paladar em pacientes submetidos a radioterapia para a região da cabeça e pescoço. Radiol Bras. 2011;44:297-300.

5. Trindade BM, Campos TPR. Sistema computacional para dosimetria de nêutrons e fótons baseado em métodos estocásticos aplicado a radioterapia e radiologia. Radiol Bras. 2011;44:109-16.

6. Tseng YD, Chen MH, Beard CJ, et al. Posttreatment prostate specific antigen nadir predicts prostate cancer specific and all cause mortality. J Urol. 2012;187:2068-73.

7. Zelefsky MJ, Shi W, Yamada Y, et al. Postradiotherapy 2-year prostate-specific antigen nadir as a predictor of long-term prostate cancer mortality. Int J Radiat Oncol Biol Phys. 2009;75:1350-6.

8. Franca CAS, Vieira SL, Penna ABRC. Definição de recidiva bioquímica após tratamento radioterápico do câncer de próstata localizado: revisão de literatura. Rev Bras Cancerol. 2008;54:57-61.

9. Ragde H, Blasko JC, Grimm PD, et al. Interstitial iodine-125 radiation without adjuvant therapy in the treatment of clinically localized prostate carcinoma. Cancer. 1997;80:442-53.

10. Trindade BM, Christóvão MT, Trindade DFM, et al. Dosimetria comparativa de braquiterapia de próstata com sementes de I-125 e Pd-103 via SISCODES/MCNP. Radiol Bras. 2012;45:267-72.

11. Nickers P, Thissen B, Jansen N, et al. ${ }^{192} \mathrm{Ir}$ or ${ }^{125} \mathrm{I}$ prostate brachytherapy as a boost to external beam radiotherapy in locally advanced prostate cancer: a dosimetric point of view. Radiother Oncol. 2006;78:47-52.

12. Zelefsky MJ, Kuban DA, Levy LB, et al. Multi-institutional analysis of long-term outcome for stages T1-T2 prostate cancer treated with permanent seed implantation. Int J Radiat Oncol Biol Phys. 2007; 67:327-33.

13. Franca CAS, Vieira SL, Carvalho ACP, et al. Localized prostate cancer with intermediate- or high-risk features treated with combined external beam radiotherapy and iodine-125 seed brachytherapy. Brachytherapy. 2010;9:307-12.

14. Kapadia NS, Olson K, Sandler HM, et al. Interval to biochemical failure as a biomarker for cause-specific and overall survival after dose-escalated external beam radiation therapy for prostate cancer. Cancer. 2012;118:2059-68.

15. Hanlon AL, Diratzouian H, Hanks GE. Posttreatment prostate-specific antigen nadir highly predictive of distante failure and death from prostate cancer. Int J Radiat Oncol Biol Phys. 2002;53:297303.

16. Kaminski JM, Hanlon AL, Horwitz EM, et al. Relationship between prostate volume, prostate-specific antigen nadir, and biochemical control. Int J Radiat Oncol Biol Phys. 2002;52:888-92.

17. Bowes D, Crook JM, Wallace K, et al. Results of a surgically derived nomogram to predict Gleason score upgrading applied to a cohort of patients with "favorable-risk" prostate cancer treated with permanent seed brachytherapy. Urology. 2012;80:649-55.

18. [No authors listed]. Consensus statement: guidelines for PSA following radiation therapy. American Society for Therapeutic Radiology and Oncology Consensus Panel. Int J Radiat Oncol Biol Phys. 1997;37:1035-41.

19. Sylvester JE, Grimm PD, Blasko JC, et al. 15-Year biochemical free survival in clinical Stage T1-T3 prostate cancer following combined external beam radiotherapy and brachytherapy; Seattle experience. Int J Radiat Oncol Biol Phys. 2007;67:57-64.

20. Nag S, Beyer D, Friedland J, et al. American Brachytherapy Society (ABS) recommedations for transperineal permanent brachytherapy of prostate cancer. Int J Radiat Oncol Biol Phys. 1999;44:789-99.

21. Franca CAS, Vieira SL, Bernabe AJS, et al. The seven-year preliminary results of brachytherapy with iodine- 125 seeds for localized prostate cancer treated at a Brazilian single-center. Int Braz J Urol. 2007;33:752-63.

22. Merrick GS, Grimm PD, Sylvester JE, et al. Initial analysis of ProQura: a multi-institutional database of prostate brachytherapy dosimetry. Brachytherapy. 2007;6:9-15.

23. Roach M 3rd, Hanks G, Thames H Jr, et al. Defining biochemical failure following radiotherapy with or without hormonal therapy in men with clinically localized prostate cancer: recommendations of the RTOG-ASTRO Phoenix Consensus Conference. Int J Radiat Oncol Biol Phys. 2006;65:965-74.

24. Miller N, Smolkin ME, Bissonette E, et al. Undetectable prostate specific antigen at 6-12 months: a new marker for early sucess in hormonally treated patients after prostate brachytherapy. Cancer. 2005;103:2499-506.

25. Buyyounouski MK, Pickles T, Kestin LL, et al. Validating the interval to biochemical failure for the identification of potentially lethal prostate cancer. J Clin Oncol. 2012;30:1857-63.

26. Pollack A, Hanlon AL, Horwitz EM, et al. Prostate cancer radiotherapy dose response: an update of the fox chase experience. J Urol. 2004;171:1132-6.

27. Symon Z, Griffith KA, McLaughlin PW, et al. Dose escalation for localized prostate cancer: substantial benefit observed with 3D conformal therapy. Int J Radiat Oncol Biol Phys. 2003;57:384-90.

28. Abdel-Wahab M, Mahmoud O, Merrick G, et al. ACR Appropriateness Criteria ${ }^{\circledR}$ external-beam radiation therapy treatment planning for clinically localized prostate cancer. J Am Coll Radiol. 2012;9: 233-8.

29. Pinkawa M, Piroth MD, Holy R, et al. Prostate-specific antigen kinetics following external-beam radiotherapy and temporary (Ir192) or permanent (I-125) brachytherapy for prostate cancer. Radiother Oncol. 2010;96:25-9.

30. Nickers P, Albert A, Waltregny D, et al. Prognostic value of PSA nadir $<$ or $=4 \mathrm{ng} / \mathrm{mL}$ within 4 months of high-dose radiotherapy for locally advanced prostate cancer. Int J Radiat Oncol Biol Phys. 2006;65:73-7.

31. Cury FL, Hunt D, Roach M 3rd, et al. Prostate-specific antigen response after short-term hormone therapy plus external-beam radiotherapy and outcome in patients treated on Radiation Therapy Oncology Group study 9413. Cancer. 2013;119:1999-2004.

32. Lee WR, Hanlon AL, Hanks GE. Prostate specific antigen nadir following external beam radiation therapy for clinically localized prostate cancer: the relationship between nadir level and diseasefree survival. J Urol. 1996;156(2 Pt 1):450-3.

33. Critz FA, Willians WH, Holladay CT, et al. Post-treatment PSA < or $=0.2 \mathrm{ng} / \mathrm{mL}$ defines disease freedom after radiotherapy for prostate cancer using modern techniques. Urology. 1999;54:968-71.

34. DeWitt KD, Sandler HM, Weinberg V, et al. What does postradiotherapy PSA nadir tell us about freedom from PSA failure and progression-free survival in patients with low and intermediate-risk localized prostate cancer? Urology. 2003;62:492-6.

35. Chen LN, Suy S, Uhm S, et al. Stereotactic body radiation therapy (SBRT) for clinically localized prostate cancer: the Georgetown University experience. Radiat Oncol. 2013;8:58. 